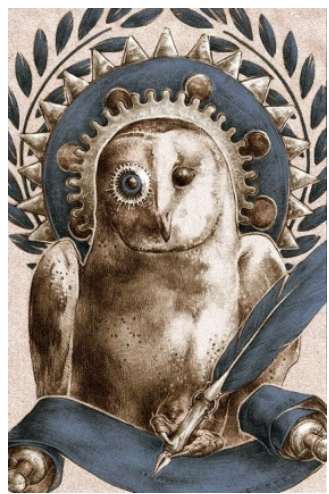

Intelligere, Revista de História Intelectual

vol. 3, no 2, out.2017

DOSSIÊ: sentido e relevância da História no mundo contemporâneo

\title{
Jörn Rüsen contra a compensação
}

\author{
Arthur Alfaix Assis \\ Prof. Adjunto do Departamento de História da Universidade de Brasília \\ arthurassis@unb.br
}

Recebido em 13/02/2017. Aprovado em 11/05/2017.

Como citar este artigo: Assis, Arthur A.. "Jörn Rüsen contra a compensação". Intelligere, Revista de História Intelectual, vol. 3, n² , p. 13-33. 2017. Disponível em < http://revistas.usp.br/revistaintelligere>. Acesso em dd/mm/aaaa.

Resumo: “Compensação" é a palavra-chave que sintetiza uma influente resposta ao problema da função das ciências humanas no mundo contemporâneo. Originária do universo da filosofia alemã da segunda metade do século 20, tal resposta sustenta, em linhas gerais, que as ciências humanas servem como uma espécie de indenização espiritual por prejuízos culturais sofridos por sociedades e indivíduos em meio à modernização (em decorrência, por exemplo, da disseminação de novas relações sociais abstratas e não-tradicionais, ou do progresso acelerado dos meios técnicos). A teoria da compensação pode ser apontada como um dos principais conjuntos de ideias a que se contrapõe a teoria da história de Jörn Rüsen. O presente texto enfoca a relação agonística entre essas duas teorias, no centro das quais está o problema do valor e da utilidade dos estudos históricos. Lançar luz sobre tal relação - esta é a minha aposta interpretativa - é uma maneira de compreender melhor aspectos importantes das reflexões de Rüsen sobre história e historiografia que até agora ainda não receberam a atenção que lhes é devida. Quero mostrar que Rüsen rejeita a teoria da compensação não só porque discorda da divisão do trabalho científico nela apregoada, a qual atribui às ciências humanas o papel relativamente modesto de tentar conservar algo daquilo que a modernidade precisa destruir. Procurarei explicar como tal rejeição também se deve a diferenças mais fundamentais existentes entre Rüsen e os teóricos da compensação, mais especificamente, às suas divergências de entendimento quanto à natureza da modernidade e quanto ao modo de configurar a complexa inter-relação entre conhecimento, política e futuro.

Palavras-chave: teoria da história; modernização; futuro; ciências humanas; formação; filosofia alemã; século 20; Joachim Ritter; Odo Marquard.

\section{Jörn Rüsen against the compensation-theory}

\begin{abstract}
Kompensation" is the keyword for an influential answer to the problem of the function of the human sciences in the contemporary world. It emerged in the second half of the twentieth-century in the field of German philosophy, and its chief message is that the human sciences have the task of compensating modern societies and individuals for cultural losses generated within the course of modernization (for instance, by the spread social relations of a new, abstract, non-traditional kind; or by the accelerating progress of technology). The compensation-theory can be stressed as one of the main ideational sets against which Jörn
\end{abstract}

Intelligere, Revista de História Intelectual revistas.usp.br/revistaintelligere 
Rüsen developed his own theory of history. This paper focuses on the agonistic relationship between these two theories that attempt to elucidate what is the value and the use of historical studies. My interpretative bet is that by doing so we will better understand important aspects of Rüsen's theoretical reflections on history and historiography that have not yet received sufficient attention. I will show that Rüsen rejects the compensation-theory not only because of he disagrees with the scientific division of labor it entails - which ascribes to the human sciences the relatively modest role of attempting to preserve some of what modernity needs to destroy. I will try to explain how that rejection is also due to more fundamental differences between Rüsen and the compensation-theorists, more specifically their differing understandings of modernity, and their dissent regarding how should the complex interrelationship between knowledge, politics, and the future be configured.

Keywords: philosophy of history; modernization; future; Humanities; Bildung; German Philosophy; 20th Century; Joachim Ritter; Odo Marquard.

Em certos setores da cultura contemporânea vigora já há muitas décadas uma tendência para a desvalorização do pensamento histórico com base na premissa de que o tipo de conhecimento do passado produzido no âmbito da historiografia acadêmica de pouco ou nada pode valer à vida atual. Essa avaliação assume que, com o avanço da profissionalização e da especialização do saber histórico, ter-se-ia aberto um fosso entre o crescente conhecimento de aspectos do passado e as intensas demandas por resolução de problemas e por gestão da experiência do tempo que emanam do presente das sociedades modernas. Quase a totalidade da historiografia acadêmica - com as suas eventuais pretensões de cientificidade ou objetividade, e a sua constante ênfase na pesquisa especializada - apenas estaria apta para resolver problemas cognitivos de baixa ou nenhuma relevância social ou cultural. A história praticada pelos historiadores profissionais formaria o exato oposto das formas de apreensão, elaboração ou construção do passado efetivamente capazes de prestar serviços à vida. ${ }^{1}$

Dentre os teóricos da história mais conhecidos na cena atual, Jörn Rüsen é um daqueles que mais fortemente têm contestado essa leitura sobre a natureza e função da ciência da história. ${ }^{2} \mathrm{Na}$ origem da sua teoria da história encontra-se justamente a preocupação em

\footnotetext{
${ }^{1} \mathrm{Na}$ sua forma moderna, essa crítica à "inutilidade" da historiografia especializada teve no jovem Friedrich Nietzsche o seu principal disseminador. Nietzsche, "Segunda consideração intempestiva: sobre a utilidade e os inconvenientes da história para a vida" [1874], in: Nietzsche, Escritos sobre história, org. trad. Noéli Correia de Melo Sobrinho (Rio de Janeiro: Ed. PUC-Rio, 2005), 67-177. A visão crítica de Nietzsche encontrou boa ressonância na literatura modernista da primeira metade do século 20. Hayden White percebeu em grandes autores do modernismo literário ocidental fortes traços de uma "revolta contra a história", quase sempre estruturada em torno da imagem dos historiadores como sujeitos obcecados pelo passado, divorciados do presente, e por isso mesmo incapazes de viver e compreender plenamente a experiência contemporânea. White, "The Burden of History", History and Theory, v. 5, n. 2, 1966, 111-134 (114-123). O próprio White é hoje o mais famoso continuador dessa tradição de crítica da historiografia. Ver, p.e. White, “The Practical Past", Historein, v. 10, 2010, 10-19 (13-15).

2 Além dos trabalhos sobre a teoria da história de Rüsen que serão referenciados mais adiante, ver também: Arthur Assis, A teoria da história de Jörn Rüsen: uma introdução (Goiânia: Ed. UFG, 2010); Pedro Spinola Pereira Caldas, "A arquitetura da teoria. O complemento da trilogia de Jörn Rüsen”, Fênix. Revista de História e Estudos Culturais, v. 5, n. 1, 2008; David Carr, "History as Orientation: Rüsen on Historical Culture and Narration", History and Theory, v. 45, n. 2, 2006, 229-243; Estevão de Rezende Martins, "Consciência histórica, práxis e cultura. A propósito da teoria da história de Jörn Rüsen”, Sintese (Nova fase), v. 19, n. 56, 1992, 59-73. Ver também o volume especial do periódico Erwägen, Wissen, Ethik (v. 22, n. 4, 2011, 477-619), contendo contribuições de cerca de cinquenta comentadores, além de uma réplica apresentada pelo próprio Rüsen. Para um panorama dos comentaristas brasileiros da obra de Rüsen, ver Wilian Carlos Cipriani Barom, "A teoria da história de Jörn Rüsen no Brasil e seus principais comentadores", História hoje, v. 4, n. 8, 2015, 223-246.
} 
construir e reformar pontes entre conhecimento e vida. ${ }^{3}$ Por esse motivo, ele fez questão de encerrar a sua trilogia teórica dos anos 1980 com um volume intitulado História viva. ${ }^{4}$ Além disso, nas últimas décadas, tem amparado boa parte das suas reflexões num conceito alargado de "cultura histórica". Tal conceito remete a um amplo espaço de práticas de representação da experiência do tempo, no qual a historiografia acadêmica especializada deixa de estar em oposição com as formas não acadêmicas de saber e de vivências históricas. ${ }^{5}$

Não por acaso, Rüsen há muito tinha colocado no centro das suas reflexões um outro conceito que também sinaliza tanto para o conhecimento quanto para a vida prática, tanto para a interpretação quanto para a ação: precisamente, o conceito de sentido. "Sentido" aponta para a conexão íntima entre a historiografia e o mundo a partir do qual e para o qual esta é produzida. O sentido histórico sintetiza experiência e intenção, conhecimento e norma, objetividade e subjetividade, fato e valor. Histórias contêm sentido (ou melhor, são elas próprias sentido constituido), e para Rüsen é precisamente por isso que podem ter relevância prática ou até mesmo "vivacidade". ${ }^{6}$

Dada a centralidade de conceitos como "sentido" e "cultura histórica", nos quadros da teoria de Rüsen, não é de espantar que ele tenha se dedicado tanto ao tema da tarefa ou função da historiografia. Ele abordou-a desde uma perspectiva que não se confunde com a compreensão tradicionalmente antiteórica que por muito tempo predominou entre os historiadores. Ao mesmo tempo, na contramão da tendência prevalecente no campo da teoria da história, evitou adotar uma atitude hipercrítica diante da historiografia realmente existente. Aqui e alhures, a teoria da história de Rüsen revela-se como um "projeto de reconciliação de extremos". 7 A resposta de Rüsen para o problema da função da ciência histórica expressa uma tentativa de síntese conciliadora, em que o pensamento histórico é apresentado com um importante vetor de orientação cultural e, mais especificamente, de formação das subjetividades e $\backslash$ ou identidades no mundo moderno.

Tal resposta, contudo, representa mais do uma reação à crítica de Nietzsche quanto aos efeitos colaterais do excesso de conhecimento histórico (e aos múltiplos desdobramentos

\footnotetext{
${ }^{3}$ Frank Ankersmit enfatizou que essa interação entre ciência especializada e vida prática é a marca distintiva da famosa matriz disciplinar da ciência histórica de Rüsen, qualificando-a como "uma radicalização do círculo hermenêutico". Ankersmit, "Rüsen on History and Politics", in: Ankersmit, Historical Representation (Stanford: Stanford University Press, 2001), 262-280 (263).

${ }^{4}$ Jörn Rüsen, História viva. Teoria da História III: formas e funções do conhecimento histórico [1989] (Brasília: Ed. UnB, 2007).

${ }^{5}$ Rüsen define a cultura histórica como "o suprassumo dos sentidos constituídos pela consciência histórica humana"; ou como "o contexto social em que se faz a história", do qual "pode surgir a profissionalização do pensamento histórico". Jörn Rüsen, Teoria da história: Uma teoria da história como ciência [2013] (Curitiba: Ed. UFPR, 2015), 217218. Na cultura histórica, tal como definida por Rüsen, podem conviver - ainda que, amiúde, de maneira tensa - a historiografia acadêmica, a historiografia popular, a erudição e a historiografia amadoras associadas por exemplo à história de localidades ou famílias, o saber histórico ensinado e aprendido nas instituições escolares; além das formas de representação histórica mobilizadas em exposições de museu, filmes, séries de televisão, documentários e docudramas, jogos eletrônicos e de tabuleiro, sites e comunidades virtuais, romances, entre outras formas de expressão cultural populares, eruditas e híbridas. Para uma excelente análise das atuais interfaces entre história e cultura popular, com ênfase na Grã-Bretanha, ver Jerome de Groot, Consuming History: Historians and Heritage in Contemporary Popular Culture (London: Routledge, 2009).

${ }^{6}$ Martin Wiklund, "Além da racionalidade instrumental: sentido histórico e racionalidade na teoria da história de Jörn Rüsen”, História da Historiografia, n. 1, 2008, 19-44 (35, 42-43).

7 Henk de Jong, "Historical Orientation: Jörn Rüsen's Answer to Nietzsche and His Followers", History and Theory, v. 36, n. 2, 1997, 270-288 (287). Ao detalhar a sua afirmação, Jong comenta de maneira perspicaz que a teoria da história de Rüsen procura realizar a mediação entre posições polares tais como: historicismo e pós-modernismo, história e utopia, racionalidade e emotividade, cultura e ciência, direitos humanos universais e relativismo cultural.
} 
dessa crítica ao longo do século 20). ${ }^{8}$ Deve também ser compreendida no contexto de um outro debate relativo à tarefa das ciências humanas (Geisteswissenschaften), travado entre eminentes filósofos alemães na segunda metade do século $20 .{ }^{9}$ Essa discussão foi inaugurada com o texto de Joachim Ritter sobre "A tarefa das ciências do espírito na sociedade moderna", publicado originalmente em 1961. O argumento de Ritter seria posteriormente levado adiante, aprofundado e adaptado por autores como Odo Marquard e Hermann Lübbe, entre outros, até ganhar dos seus antagonistas o apelido de "teoria da compensação". Em linhas gerais, tal teoria sustenta que as ciências humanas servem como uma espécie de indenização espiritual por prejuízos culturais causados a sociedades e indivíduos pelo processo modernizador (no bojo, por exemplo, da disseminação de novas relações sociais abstratas e não-tradicionais, ou do acelerado progresso dos meios técnicos). ${ }^{10}$

A teoria da compensação pode ser apontada como um dos principais conjuntos de ideias a que se contrapõe a teoria da história de Jörn Rüsen. O presente texto enfoca a relação agonística entre essas duas teorias, no centro das quais está o problema do valor e da utilidade dos estudos históricos. Lançar luz sobre tal relação - esta é a minha aposta interpretativa - é uma maneira de compreender melhor aspectos importantes das reflexões de Rüsen sobre história e historiografia que até agora ainda não receberam a atenção que lhes é devida. Quero mostrar que Rüsen rejeita a teoria da compensação não só porque discorda da divisão do trabalho científico nela apregoada, a qual atribui às ciências humanas o papel relativamente modesto de tentar conservar algo daquilo que a modernização ameaça destruir. Procurarei explicar como tal rejeição também se deve a diferenças mais fundamentais existentes entre Rüsen e os teóricos da compensação, mais especificamente, às suas divergências de entendimento quanto à natureza da modernidade e quanto ao modo de configurar a complexa inter-relação entre conhecimento, política e futuro.

Uma interpretação desse tipo, se bem-sucedida, pode também carregar consigo uma inusitada espécie de bônus metodológico: a demonstração de que uma maneira fecunda de interagir cognitivamente com teorias (históricas, ou de qualquer outro tipo) é aquela em que o esforço da exegese filosófica se comuta em história intelectual, e vice-versa.

\footnotetext{
${ }^{8}$ Para uma análise da teoria da história de Rüsen como uma resposta a Nietzsche e ao pós-modernismo historiográfico, ver, de novo, Jong, "Historical Orientation".

9 Aqui e abaixo faço Geisteswissenschaften equivaler preferencialmente a "ciências humanas", evitando assim o termo "ciências do espírito". Recorro a este último termo, creio, apenas nos casos em que traduzo diretamente uma ou outra passagem de textos de Ritter e Marquard. Na língua portuguesa, "ciências do espírito" parece demasiado artificial e algo misterioso. "Ciências humanas", no entanto, é menos carregado de ressonâncias metafísicas idealistas do que Geisteswissenschaften e por isso tal opção vocabular é menos literal do que “ciências do espírito". De qualquer modo, é importante ter em mente que, assim compreendidas, as ciências humanas tanto englobam o que se pode chamar, no singular, de ciência (ou disciplina) histórica, quanto são elas próprias marcadas pela perspectiva histórica. Uma vez que, por isso, as ciências humanas são "ciências históricas", aplicam-se a elas parte considerável da reflexão sobre teoria e métodos da ciência histórica. É, aliás, esta convergência de significados que permite relacionar autores como Ritter e Marquard, que falam em Geisteswissenschaften, a um autor como Rüsen, que fala sobretudo em Geschichswissenschaft (além de, mais recentemente, Kulturwissenschaften).

${ }^{10}$ Joachim Ritter, "La tarea de las ciencias del espíritu en la sociedad moderna" [1961], in: Ritter, Subjetividad. Seis ensayos (Barcelona: Alfa, 1986), 93-123; Hemann Lübbe, Geschichtsbegriff und Geschichtsinteresse. Analytik und Pragmatik der Historie [1977] (Basel: Schwabe, 2012), 324-356; Odo Marquard, "Sobre la inevitabilidad de las ciencias del espíritu" [1985], in: Marquard, Apología de lo contingente. Estudios filosóficos (Valencia: Institució Alfons el Magnanim, 2000), 109-125. Marquard aborda o tema da compensação em diversos outros textos, alguns dos quais serão referenciados mais adiante.
} 
O interesse de Jörn Rüsen por questões fundamentais ligadas à relação entre existência, experiência e significado (ou sinntheoretische Fragen, como ele costuma dizer) precede o seu engajamento com temas de filosofia e histórica acadêmicas. Numa entrevista datada de 2012, ele menciona que na adolescência se interessou vivamente por filosofias e religiões orientais: leu, entre outros, Confúcio e Lao-Tse, começou um curso de sânscrito com a intenção de ler o Bhagavad Gita em versão original e praticou ioga com seriedade. Ao iniciar os seus estudos universitários, em 1958, Rüsen até mesmo cogitou estudar indologia, mas não levou a ideia adiante porque não provinha de família abastada e não podia se dar ao luxo de fazer uma opção tão arriscada do ponto de vista do futuro profissional. ${ }^{11} \mathrm{O}$ plano de se tornar professor ginasial - para o qual contribuiu um certo sentido de vocação pessoal, além da intenção de ascender socialmente ${ }^{12}$ - levou-o então a direcionar as questões fundamentais que o interessavam para as zonas de cruzamento entre a filosofia e a história. É sobre esta base que se foram sedimentando, no médio e no longo prazos, as suas teorias do conhecimento, da consciência e da cultura históricas, bem como as suas interpretações sobre a história do pensamento histórico.

Em todos esses níveis de teorização, Rüsen amiúde associa a função do conhecimento histórico a uma das noções mais intraduzíveis do vocabulário filosófico alemão: o conceito de Bildung, de formação individual. A história desta palavra e dos significados a ela associados revela uma complexa trajetória, que abarca a teologia e a mística tardo-medievais, além do movimento pietista - um movimento de renovação da espiritualidade protestante que marcou fortemente a história da cultura, das sociedades e também das famílias em muitas regiões de língua alemã nos séculos 17 e 18. Os limites modernos do campo semântico do termo, no entanto, foram definidos no contexto do idealismo e do neo-humanismo de inícios do século 19. Desde então, o termo foi secularizado e passou a apontar para o impulso subjetivo para o cultivo de si, guiado por ideias de perfectibilidade e progresso, e realizado por meio do contato intensivo com as grandes realizações culturais acumuladas pela humanidade, sobretudo nos campos das artes, da filosofia, das humanidades e das ciências. ${ }^{13}$

Quando fala em "formação" mediada pelo conhecimento histórico, Rüsen está atribuindo a este último uma função prática. "Formação", enquanto produto da aprendizagem histórica, ao mesmo tempo descreve e idealiza o melhor tipo de relação entre o saber teórico e a subjetividade que se apropria de tal saber. Articula, nas palavras do próprio autor, "o máximo de orientação com o máximo de autoconhecimento, possibilitando assim o máximo de autorealização ou de reforço identitário". ${ }^{14}$ Deste modo, o processo formativo corresponde ao desenvolvimento das competências interpretativas que podem, condignamente, religar o

11 Jörn Rüsen, "Interview geführt von Thomas Sandkühler" [30. Januar 2012], in: Historisches Lernen denken: Gespräche mit Geschichtsdidaktikern der Jahrgänge 1928-1947, org. Thomas Sandkühler (Göttingen: Wallstein Verlag, 2014), 251-292 (256-257). Entre outras coisas, Rüsen menciona que apenas pode estudar na Universidade de Colônia por ter sido dispensado do pagamento de taxas e por ter recebido bolsa de estudo.

12 Rüsen, "Interview geführt von Thomas Sandkühler", 257-258.

${ }^{13}$ Sobre o conceito de Bildung e a sua história ver: Georg Boellenbeck, Bildung und Kultur. Glanz und Elend eines deutschen Deutungsmusters (Frankfurt am Main: Suhrkamp, 1996), 96-159; Ernst Liechtenstein, "Bildung", in: Historisches Wörterbuch der Philosophie, Band 1, org. Joachim Ritter (Basel: Schwabe \& Co., 1971), 921-937; Peter Watson, The German Genius. Europe's Third Renaissance, the Second Scientific Revolution, and the Twentieth Century (London: Simon \& Schuster, 2010), 65-90.

${ }^{14}$ Rüsen, História viva, 95. 
conhecimento histórico à vida. Para Rüsen, isso é possível na medida em que a formação atua como um antídoto para uma das principais ameaças que se colocam ao caráter prático do saber histórico, a saber, a que se manifesta na sua irreversível tendência para a especialização, vigente desde pelo menos a metade do século 19.

Rüsen está longe de querer contribuir para uma refutação antimodernista da especialização que caracteriza a pesquisa histórica contemporânea. Mas, por outro lado, ao conferir tamanha atenção ao tema da formação, ele faz questão de ressaltar que o pensamento histórico vai bem além da simples análise pormenorizada do material das fontes e da exposição de resultados de investigação. Se, como afirma Rüsen, na fase da pesquisa, o historiador vira as costas para o seu presente, tal circunstância não implica numa anulação da "base existencial do pensamento histórico". ${ }^{15}$ Reestabelecer o contato com tal base existencial é, com efeito, a tarefa da representação histórica, e Rüsen insiste que o caminho de volta do conhecimento ao mundo da vida prática não termina aí. Representações - e isso é para ele de importância central - destinam-se a produzir impactos sobre os destinatários das histórias, podendo, quando tudo corre bem, atuar sobre a subjetividade destes como indutoras de processos formativos. Se isso acontece, o ganho cognitivo atingido na pesquisa integra-se de modo bem-sucedido ao horizonte prático do presente. À subjetividade formada no exercício do pensamento histórico abrem-se possibilidades de orientação do agir que inexistem forma do âmbito histórico. $\mathrm{Na}$ formação, na Bildung, que para Rüsen nada mais é senão "subjetividade temporalizada", ${ }^{16}$ resolve-se a tensão entre ciência e vida, gerada em meio ao processo cognitivo.

Na ênfase de Rüsen na formação está embutida, enfim, uma aposta na possibilidade de evitar que da pressão por especialização, que no mundo moderno incide poderosamente sobre a pesquisa histórica, resultem subjetividades atomizadas, incapazes de compreender os contextos abrangentes relacionáveis às informações obtidas mediante pesquisa e de relacionar o saber histórico à vida prática. ${ }^{17} \mathrm{Com}$ isso, o conhecimento histórico poderia então atuar não só sobre a própria comunidade historiográfica, mas também sobre o universo social mais abrangente em que tal comunidade está enraizada. A noção de formação, tão proeminente na análise de Rüsen da função do conhecimento histórico, aponta para todos esses resultados. Ao explorá-la, Rüsen procurou remediar a ansiedade inicialmente vocalizada por Nietzsche, que em 1874 designou de "doença histórica" a inflação do conhecimento pormenorizado sobre o passado e os efeitos paralisantes que tal excedente cognitivo geraria sobre a capacidade de ação individual. ${ }^{18}$ Para Rüsen, a ameaça cultural de que falava Nietzsche pode ser desfeita quando o conhecimento histórico é mobilizado como recurso de orientação por uma subjetividade "formada" para pensar historicamente, ou seja para interagir com o mundo atual de uma maneira que está longe de se esgotar no mero acúmulo de saberes pontuais e fragmentários. ${ }^{19}$

\footnotetext{
15 Rüsen, História viva, 39.

${ }^{16}$ Rüsen, Teoria da história, 209.

17 Rüsen, História viva, 95. Bildung, a propósito, já no contexto do iluminismo tardio e do nascente idealismo, sinalizava para uma maneira específica de educação, de cultivo de si, como um fim em si mesmo, estabelecendo-se em oposição à instrução prática dirigida pela noção de finalidade. Hubert Cancik, "Entrohung und Barmherzigkeit, Herrschaft und Würde. Antike Grundlagen von Humanismus", in: Streit um den Humanismus, org. Richard Faber (Würzburg: Könighausen und Neumann, 2003), 23-42 (37-39).

${ }^{18}$ Nietzsche, "Sobre a utilidade e os inconvenientes da história para a vida", 172.

${ }^{19}$ Rüsen, Teoria da história, 143-148.
} 
Mas há, contudo, para Rüsen, formas e formas de formação, e nem todas conduzem à conciliação entre teoria e prática vislumbrada por ele. Ao lado daquela formação capaz de colocar ciência e vida numa relação de complementariedade, Rüsen encontra uma formação de cunho compensatório, em que a racionalidade do trabalho do historiador é separada das demandas por orientação provenientes do seu ambiente cultural. Nesse segundo caso, a historiografia acadêmica, a ciência da história, abriria mão de interagir diretamente com o mundo da vida, cedendo terreno para outras formas culturais - sobretudo, para as artes. Tal deslocamento acabaria por comprometer "irreversivelmente a dimensão cognitiva da compreensão humana do mundo e a auto-interpretação dos homens". ${ }^{20}$ Entendida enquanto mera compensação, conclui Rüsen, a formação "reforça a ignorância do geral por parte do especialista, [...] e a debilidade dos sujeitos, que se sentem como engrenagens do maquinário". ${ }^{21}$

Rüsen associa, pois, o modo compensatório de formação a uma compreensão deficiente do problema da função do conhecimento histórico, com a qual se postula que a racionalidade metódica que guia o trabalho do historiador não pode ser aproveitada no contexto da vida prática do presente. Esse divórcio entre conhecimento e prática, todavia, pode, para ele, ser evitado contanto que se opte por uma compreensão alternativa de formação, na qual ambos se situam numa complexa relação de complementariedade.

É relevante que Rüsen use o termo "compensação" para designar aquilo que ele pensa que não deve ser a essência da tarefa da historiografia. De fato, esse termo ganhou espaço na discussão alemã sobre a relevância e função do conhecimento sob o patrocínio de Joachim Ritter - um dos mais importantes filósofos da Alemanha pós-1945, que é sempre lembrado como o idealizador do Dicionário Histórico da Filosofia e de cujo Collegium philosophicum saíram alguns dos mais influentes nomes da filosofia alemã contemporânea. ${ }^{22}$ Odo Marquard é um dos mais conhecidos egressos do seminário de Ritter. É precisamente contra os contornos específicos conferidos por Marquard à tese da compensação que Rüsen definiu a sua própria interpretação da função cultural da historiografia e das ciências humanas em geral.

No seu ensaio sobre "A tarefa das ciências do espírito na sociedade moderna", Ritter retoma e reinterpreta a teoria da modernidade elaborada por Hegel, especialmente no âmbito da sua teoria política. O mundo moderno ter-se-ia constituído em meio a uma complexa dinâmica de ruptura e continuidade em relação ao seu próprio passado, dinâmica essa que fora capturada por Hegel num termo central à sua filosofia: Entz̧weinng. Ritter ressalta que neste termo está embutida a tese de que a tensão moderna entre origem (Herkunft) e futuro (Zukunft),

\footnotetext{
${ }^{20}$ Rüsen, História viva, 96.

${ }^{21}$ Rüsen, História viva, 97.

22 Jürgen Seifert, "Joachim Ritters 'Collegium Philosophicum”, in: Kreise - Gruppe - Bünde. Zur Soziologie modernen Intellektuellenassoziation, org. Richard Faber; Christine Holste (Würzburg: Könighausen \& Neumann, 2000), 189-198. Dentre os intelectuais de grande destaque na Alemanha dos anos 1950 em diante que, de um modo ou de outro, nos seus respectivos períodos formativos estiveram ligados ao seminário de Ritter na Universidade de Münster, podem-se destacar os seguintes: os filósofos Karlfried Gründer, Friedrich Kambartel, Hermann Lübbe, Odo Marquard, Reinhart Maurer, Willi Oelmüller, Günter Rohrmoser, Hans Jörg Sandkühler, Robert Spaemann, Gunter Scholtz, Ernst Tugendhat; os juristas Ernst-Wolfgang Böckenförde e Martin Kriele; os cientistas políticos Jürgen Seifert e Bernard Willms; além dos historiadores Max Imdahl e Rudolf Vierhaus.
} 
a disjunção entre o devir e o porvir, não pode ser dissolvida numa descontinuidade absoluta, devendo antes ser concebida sob a forma de uma complexa de continuidade histórica. ${ }^{23} \mathrm{O}$ caso da Revolução Francesa ilustra de maneira exemplar como isso ocorre: aqui a negação radical da ordem histórica pré-existente - a ruptura dos princípios políticos, sociais, filosóficos e teológicos estruturantes das formas de vida da velha Europa à época do absolutismo - é apenas uma das facetas de um processo mais abrangente. É que, para Hegel, tal como interpretado por Ritter, a Revolução, precisamente ao negar essas tradições imediatas, propiciou a continuidade da materialização na história mundial de um legado muito mais recuado no tempo: a ideia de liberdade inaugurada no contexto da polis antiga. ${ }^{24}$

No mundo moderno, segundo a interpretação histórico-filosófica que Ritter adapta de Hegel, a tendência à abstração e à homogeneização contrapõe-se à historicidade concreta de sociedades e indivíduos, e disso resultam tanto perdas quanto ganhos culturais. O principal ganho seria o pensamento universalista que permite que as pessoas se concebam a si próprias e às demais enquanto seres abstratamente iguais e, por isso, igualmente capazes de se converterem em sujeitos de direitos. Mas essa igualdade dos seres humanos enquanto tais esvazia a historicidade da vida social, afastando as pessoas das tradições e práticas herdadas do passado - adquiridas, por exemplo, no contexto da família, da vida religiosa, ou do exercício da moralidade. ${ }^{25}$ Rechaçando ao mesmo tempo concepções revolucionárias e restaurativas de história (que absolutizam, respectivamente, o futuro e o passado), Ritter sugere que, nas sociedades modernas, é inextinguível a tensão entre historicidade concreta e liberdade abstrata. Como sublinhou Odo Marquard, para Ritter, "O mundo moderno e as suas instituições não são nem idílio, nem inferno, estando aí para serem aceitos de modo sóbrio". ${ }^{26}$

O diagnóstico apresentado por Ritter supõe que a descontinuidade instaurada à época da Revolução Francesa seja um traço central de uma dialética histórica que se processa dentro de parâmetros complexos, se bem que, ao fim e ao cabo, racionais. A sua filosofia da modernidade afasta-se da de Hegel, na medida em que Ritter renuncia à tentativa de fundamentar teoricamente as leis ou princípios gerais que estariam subjacentes ao decurso da história do mundo. ${ }^{27}$ Mesmo assim, não deixa de corresponder a uma filosofia substantiva da história, ainda que atenuada. A tarefa das ciências humanas tal como definida por Ritter responde, portanto, a uma conjuntura civilizacional alargada, pensada desde a perspectiva da história mundial. Essas ciências inserem-se, assim, na dinâmica da moderna Entraveiung. Cabelhes neste contexto fornecer compensação pelas perdas que a modernização acarreta ao mundo da vida, por exemplo, na medida em que práticas sociais abstratas, universalistas, homogeneizantes e tecnificadas ganham terreno em relação às práticas tradicionais. ${ }^{28}$ As ciências humanas, no entender de Ritter, justificam-se enquanto um modo necessária de

${ }^{23}$ Mark Schweda, Entzweiung und Kompensation. Joachim Ritters philosophische Theorie der modernen Welt (Freiburg: Alber, 2013), 121-126.

${ }^{24}$ Schweda, Entzweiung und Kompensation, 114-121.

${ }^{25}$ Ritter, "La tarea de las ciencias del espíritu en la sociedad moderna", 115-116.

${ }^{26}$ Odo Marquard, "Ritter, Joachim", Neue Deutsche Biographie 21, 2003, 663-664 (664).

${ }^{27}$ Schweda, Entzweiung und Kompensation, 371-373.

${ }^{28}$ Ritter, "La tarea de las ciencias del espíritu en la sociedad moderna", 116-117. 
conhecimento uma vez que logram manter presente à sociedade moderna "aquilo que ela se vê obrigada a por para fora de si", ${ }^{29}$

Ao dar centralidade à compensação como mecanismo cultural fundamental das sociedades modernas, Ritter mobilizou um conceito cujas origens remontam, pelo menos, à teodiceia de Leibniz, para quem o criador introduziu na natureza "milhares de comodidades", a fim de compensar os males nela existentes. A pré-história do conceito abrange ainda a teoria da história de Burckhardt, a tradição psicanalítica, além das antropologias filosóficas de Helmuth Plessner e Arnold Gehlen. ${ }^{30}$ Estes últimos são precisamente os autores que mais diretamente influenciaram o uso do termo por Ritter, algo que ocorre sobretudo no âmbito teoria das ciências humanas e da estética. No primeiro caso - o único que interessa, no presente contexto -, compensação liga-se à função cultural das humanidades, definidas enquanto ciências históricas e hermenêuticas do espírito. Uma tal atribuição de função permitiria entender que não há nada de paradoxal quando a obsolescência de tradições, costumes, utensílios, vestimentas, edificações, etc., se faz acompanhar do desenvolvimento de práticas de conservação, compreensão, musealização e atualização de elementos eliminados da prática social no decurso do próprio processo de modernização. Um vetor crucial da "compensação" é, portanto, para Ritter, o desenvolvimento, consumado no século 19, de um "sentido histórico" que orienta os seres humanos para a conservação e o estudo de resíduos do passado, o próprio e o alheio, e que torna chocante a naturalidade com que, noutras épocas e culturas, foram destruídos ou readaptados edifícios, monumentos e objetos antigos. ${ }^{31} \mathrm{Um}$ tal sentido histórico, nas palavras de Ritter, "plasma-se e realiza-se nas ciências do espírito", dando suporte a uma forma especificamente moderna de comportamento frente ao passado. ${ }^{32}$

Odo Marquard, que foi aluno e depois assistente de Ritter em Münster, também foi certamente o mais ardoroso continuador da tese da compensação. ${ }^{33}$ Após o falecimento de Ritter, ocorrido em 1974, ele levaria adiante o insight deste sobre o papel compensatório das ciências humanas, projetando-o sobre novos temas e enquadrando-o no âmbito de uma teoria política decididamente cética e antiutópica. Ampla repercussão sobre as discussões de política acadêmica do momento em que Rüsen sistematizava a sua teoria da história foi gerada pela conferência "Sobre a inevitabilidade das ciências do espírito", proferida por Marquard em 1985. ${ }^{34}$ Ele falava então na abertura da reunião anual da Associação dos Reitores de Escolas Superiores da Alemanha Ocidental, na qualidade de presidente da Sociedade Alemã de

\footnotetext{
${ }^{29}$ Ritter, "La tarea de las ciencias del espíritu en la sociedad moderna", 119.

30 Odo Marquard, "Homo compensator. Zur anthropologischen Karriere eines metaphysischen Begriffes", in: Marquard, Philosophie des Stattdessen: Studien (Stuttgart: Reclam, 2000), 11-29 (12-16).

${ }^{31}$ Ritter, "La tarea de las ciencias del espíritu en la sociedad moderna", 112-113.

32 Ritter, "La tarea de las ciencias del espíritu en la sociedad moderna", 112.

${ }^{33}$ Para uma rápida e precisa visão geral do pensamento e da trajetória de Marquard, ver Jürgen Kaube, "Wir Menschen sind stets mehr unsere Zufälle als unsere Wahl. Zum Tod Odo Marquards”, FAZ, 11.05.2015.

${ }^{34}$ Marquard, "Sobre la inevitabilidad de las ciencias del espíritu".
} 
Filosofia, e tal circunstância muito terá contribuído para a ressonância das ideias então apresentadas e para a controvérsia em torno da "teoria da compensação" que se seguiu. ${ }^{35}$

$\mathrm{Na}$ esteira de Ritter, Marquard afirma que a modernização - que tem nas ciências da natureza um dos seus mais ativos motores - conduz a uma artificialização acelerada das formas e condições de vida, com a qual a realidade é desnaturalizada, objetivicada, ou deshistoricizada. Esses processos equivalem a danos culturais que não podem ser revertidos, mas o fundamental para Marquard é que as sociedades modernas desenvolveram mecanismos de compensação que lhes fornecem uma espécie de indenização espiritual da mais alta importância. À moderna objetificação da realidade natural contrapõe-se, por exemplo, o desenvolvimento de uma igualmente moderna sensibilidade para a contemplação e a preservação da natureza. Outrossim, a moderna "perda de história" é reciprocada pelo desenvolvimento de um sentido histórico que valoriza e estimula a preservação dos restos de tempos pretéritos. ${ }^{36}$ É por causa da existência e eficácia dessas formas de compensação cultural que Marquard pode afirmar que "nenhuma época destruiu tanto quanto a época moderna; nenhuma época preservou tanto quanto a época moderna". 37

As ciências humanas, no entender de Marquard, estão fundamentalmente ligadas a esse trabalho de compensação. Existem, em última análise, em função da necessidade de tornar o processo modernizador melhor suportável. Desse modo, para ele, "quanto mais moderno se torna o mundo moderno, mais inevitáveis se tornam as ciências do espírito". ${ }^{38}$ Elas produzem um repositório de interpretações e narrativas capazes de tornar familiares mundos originários que estão para se tornar estranhos, servindo assim de contrapartidas à a-historicidade estimulada pelas ciências naturais. Assim definidas, as ciências humanas deixam de ser vistas como hostis ou resistentes à modernidade, passando, ao contrário, a representar um fenômeno tipicamente moderno, que apenas pôde emergir após o estabelecimento das modernas ciências experimentais. ${ }^{39}$

Marquard avança para além da posição de Ritter na medida em que define as ciências humanas não apenas como ciências históricas e hermenêuticas, mas também como "ciências

\footnotetext{
${ }^{35}$ Schweda, Entzweiung und Kompensation, 154; 406-407. Na história dessa polêmica destacam-se, entre outros, os contrapontos e críticas apresentados em: Herbert Schnädelbach, "Kritik der Kompensation”, Kursbuch, n. 91, 1988, 35-45; Wolfgang Kersting, "Hypolepsis und Kompensation - Odo Marquards philosophischer Beitrag zur Diagnose und Bewältigung der Gegenwart“", Philosophische Rundschau, v. 36, n. 3, 1989, 161-186 (181-186); Jürgen Mittelstrasss, Glanz und Elend der Geisteswissenschaften (Oldenburg: Bibliotheks- und Informationssystem der Universität Oldenburg, 1989), 10-14. Marquard rebateu algumas das objeções levantadas à sua tese em "Verspätete Moralistik. Bemerkungen zur Unvermeidlichkeit der Geisteswissenschaften”, FAZ, 18.03.1987.

${ }^{36}$ Marquard, "Sobre la inevitabilidad de las ciencias del espíritu", 113-114; 117. Uma outra variante da compensação relaciona-se com o desenvolvimento do moderno sentido estético e manifesta-se de modo exemplar na importância cultural do romance. Ver: Odo Marquard, "Narrare necesse est", in: Marquard, Philosophie des Stattdessen. Studien (Stuttgart: Reclam, 2000), 60-65 (62).

${ }^{37}$ Marquard, "Sobre la inevitabilidad de las ciencias del espíritu", 117.

${ }^{38}$ Marquard, "Sobre la inevitabilidad de las ciencias del espíritu", 109.

39 Odo Marquard, "Philosophie des Stattdessen. Einige Aspekte der Kompensationstheorie", in: Marquard, Philosophie des Stattdessen. Studien (Stuttgart: Reclam, 2000), 30-49 (32); Marquard, "Sobre la inevitabilidad de las ciencias del espíritu”, 116. A enfática e recorrente afirmação de Marquard de que as ciências do espírito apenas teriam surgido depois das ciências naturais experimentais parece-me demasiado simplificadora. Gunter Scholtz apontou para os problemas embutidos nesta e noutras concepções relativas às origens das ciências humanas ou do espírito, um dos quais é o fato de postularem cronologias que não se sustentam quando se considera a história das disciplinas particulares que comporiam as humanidades. Por exemplo, não seria errado afirmar que já os mesopotâmios em 3.000 a.C. praticavam a filologia, ou que a ciência da música surgiu com Pitágoras. Gunter Scholtz, "Zu Begriff und Ursprung der Geisteswissenschaften”, in: Scholtz, Zwischen Wissenschaftsanspruch und Orientierungsbedürfnis. Zu Grundlage und Wandel der Geisteswissenschaften (Frankfurt am Main: Suhrkamp, 1991), 17-35 (32-33). Também, acrescento eu, a história da historiografia passa a ser vista de maneira excessivamente redutora quando se desprezam como "não-científicas" as práticas historiográficas pré-modernas ou não ocidentais.
} 
que narram" (erzählende Wissenschaften)..$^{40}$ Essa definição guarda semelhanças com o narrativismo que inspira a teoria da história de Rüsen, ainda que este esteja voltado para a resolução de problemas de caráter primariamente epistemológico, ${ }^{41}$ enquanto que na abordagem mais marcadamente antropológica de Marquard tais problemas são simplesmente deixados de lado. A fundamentação antropológica da teoria da compensação também é fonte de uma outra diferença - esta de enorme importância (ainda que frequentemente negligenciada) - entre as concepções de modernidade de Marquard e Ritter. A partir do início dos anos 1970, Marquard define-se, no cenário filosófico alemão, como um dos mais incisivos críticos das "ideias de 68".42 Num contexto de grande polarização política em que a jovem Bundesrepublik foi submetida a decisivos testes de stress, Marquard investiga e critica por diversos ângulos a tradição da filosofia substantiva da história, não por último como uma estratégia para desmontar o substrato ideacional que então embasava as expectativas utópicas de intelectuais e estudantes à sua esquerda. A sua atitude crítica e irônica diante de boa parte do pensamento e ação das esquerdas da época ficou registrada de maneira lapidar na primeira frase daquela que é talvez a sua principal obra, Dificuldades com a filosofia da história, publicada em 1973: "Os filósofos da história têm transformado o mundo de diferentes maneiras; chegou a hora de o deixar em paz". ${ }^{43}$

Ocorre que, como indiquei anteriormente, também a tese da compensação de Ritter, muito embora estivesse longe de despertar entusiasmo junto à “oposição extraparlamentar" e aos seus simpatizantes, também estava fortemente ancorada em pressupostos e conceitos de natureza histórico-filosófica. Marquard nunca polemizou contra a filosofia da história presente nas teses centrais do seu professor, mas é inegável que o pesado ataque por ele desferido contra os desdobramentos contemporâneos da filosofia da história marxista ricocheteia sobre a obra de Ritter. Depois de ter exposto tão enfaticamente as suas dificuldades com a moderna filosofia da história, restou-lhe realocar a teoria da compensação de Ritter no território de uma antropologia filosófica pronunciadamente cética, e, portanto, muito mais tendente a se concentrar naquilo que o ser humano não pode ser que naquilo que este pode ser. ${ }^{44}$

Com tudo isso, o pensamento de Marquard passa a se situar decididamente à direita do de Ritter. Marquard fica longe de poder ser alçado à condição de reacionário, pois admite de bom grado a legitimidade da época moderna, não fazendo de modo algum apologia de ordens sociais ou formas de dominação distintas daquelas que caracterizam as democracias liberais ocidentais. Mas nem por isso ele escapa à acusação de que seria conservador ou tradicionalista. A sua crítica à filosofia da história e a sua defesa da ordem sócio-política estabelecida em boa parte do mundo ocidental após a Segunda Guerra Mundial são os dois

\footnotetext{
40 Marquard, "Narrare necesse est”, 63. Mark Schweda afirma, a meu ver apressadamente, que simplesmente por ter adotado essa compreensão narrativista Marquard teria jogado fora a pretensão de objetividade tradicionalmente cultivada nas reflexões epistemológicas e metodológicas sobre as ciências humanas, aproximando-se assim de uma hermenêutica de cariz pós-moderno. Schweda, Entzweiung und Kompensation, 408.

${ }^{41}$ Curiosamente, a virada de Rüsen para uma postura narrativista diante dos problemas fundamentais do conhecimento histórico deu-se a partir da recepção da teoria da historiografia de Arthur Danto, introduzida na Alemanha pelo filósofo Hans-Michael Baumgartner. Jörn Rüsen, “Theory of History as Aufklärung. Interview conducted by Sérgio da Mata e Valdei Lopes de Araújo”, História da Historiografia, n. 11, 2013, 339-353 (342-343).

${ }^{42}$ A expressão é de Norbert Frei. Ver Frei, 1968. Jugendrevolte und globaler Protest (Bonn: BpB, 2008), 211-218.

43 Odo Marquard, Schwierigkeiten mit der Geschichtsphilosophie. Aufsätze (Frankfurt am Main: Suhrkamp, 2002$), 13$.

Ver: Sérgio da Mata, "Marquard, Odo. Las dificultades con la filosofía de la historia" (Resenha), História da Historiografia 1 (2008), 108-114.

${ }^{44}$ Schweda, Entzweiung und Kompensation, 412-414.
} 
lados da mesma moeda.45 A filosofia de Marquard corporifica um "tradicionalismo da modernidade", ${ }^{46}$ estruturado como forma de ajudar a conservar a democracia liberal, a cidadania e o estilo de vida da classe média em meio ao ambiente hostil gerado pela onda mundial de protestos do final dos anos 1960. À luz dela, projetos abrangentes de transformação ou superação da ordem existente são encarados, em princípio, com ceticismo. São, na verdade, descartados, até prova em contrário. Como ele - e também outros antigos companheiros do Collegium Philosophicum de Munster que vivenciaram uma virada semelhante para o liberalismo-conservador ao longo da década de 1960 - costumava dizer, o ônus da prova cabe àqueles que querem a mudança. ${ }^{47}$

5

Com efeito, ceticismo, pragmatismo, sobriedade, desconfiança diante de ideologias e projetos grandiloquentes de futuro formam um conjunto de atitudes e emoções que esteve na base do pensamento político de intelectuais cuja adolescência ou juventude transcorreu em meio à Segunda Guerra Mundial. Intelectuais como Marquard (1928-2015), Lübbe (1926-), Koselleck (1923-2006), entre outros tantos, são frequentemente lembrados como integrantes da coorte que o sociólogo Helmut Schelsky designou de "geração cética". Marquard, ele próprio, aceita de bom grado essa classificação, ao lembrar que a sua virada pessoal para o ceticismo estava longe de ser um caso isolado entre os jovens intelectuais da Alemanha do pós-guerra. ${ }^{48}$

Historicizando e criticando a terminologia de Schelsky, Dirk Moses mostrou recentemente que o ceticismo antiutópico acima descrito esteve, todavia, longe de ser uma unanimidade entre a "geração de 45". De fato, traço comum entre essa geração de pessoas nascidas entre meados dos anos 1920 e 1933 foram experiências como a politização compulsória no âmbito da Juventude Hitlerista (frequentemente acompanhada de longas passagens como soldado e prisioneiro de guerra), além da posterior adesão aos valores e instituições da Bundesrepublike, no pós-guerra. ${ }^{49}$ Mas em resposta a essas experiências, sublinha Moses, emergiram, pelo menos, duas "linguagens políticas" distintas - e que se revelariam igualmente importantes do ponto de vista da consolidação de uma cultura política liberal e democrática na Alemanha Ocidental: de um lado, a linguagem do "republicanismo redentor", à base de um pensamento político radical que aspirava a uma ruptura catártica com o traumático passado alemão; e, do outro, a linguagem do "republicanismo integrativo", associada a uma postura política moderada e reformista, mais disposta a integrar ao menos parte da herança nacional-socialista na ordem que se seguiu à "catástrofe alemã", 50

\footnotetext{
45 Schweda, Entzweiung und Kompensation, 416-419.

${ }^{46}$ Odo Marquard, “Ich bin ein Weigerungsverweigerer': Ein Gespräch mit Odo Marquard. Die Fragen stellten Jens Hacke”, in: Marquard, Skepsis in der Moderne. Philosophische Studien (Stuttgart: Reclam, 2007), 13-22 (20).

${ }^{47}$ Odo Marquard, "Ich bin ein Weigerungsverweigerer", 16.

48 Odo Marquard, “Abschied vom Prinzipiellen. Auch eine autobiographische Einleitung”, in: Marquard, Abschied vom Prinzipiellen. Philosophische Studien (Stuttgart: Reclam, 2010), 4-22 (5-6).

${ }^{49}$ A. Dirk Moses, German Intellectuals and the Nazi Past (Cambridge: Cambridge University Press, 2007), 58-59, 6465.

${ }^{50}$ Moses, German Intellectuals and the Nazi Past, 40-41, 69-73.
} 
Tendo nascido em outubro de 1938, Jörn Rüsen mal havia deixado a primeira infância quando do término da II Guerra Mundial e, por isso, não se encaixa bem na "geração de 45". ${ }^{51}$ Por outro lado, em 1968, Rüsen já era um jovem adulto de 30 anos, relativamente apolítico, se bem que com firmes convicções antimarxistas. ${ }^{52}$ Tudo isso faz com que ele também não se encaixe bem na "geração de 68 ".

Na verdade, dos anos 1960 aos 1980, a atividade intelectual de Rüsen processou-se dentro do horizonte conceitual, retórico e emocional formado por autores da primeira geração e não da segunda. Mas o curioso é que o exame dos aspectos políticos e metapolíticos da obra de Rüsen revela traços dos dois tipos de republicanismo definido por Moses na sua interpretação da história intelectual alemã da segunda metade do século 20. Tal como os historiadores sociais Hans-Ulrich Wehler e Jürgen Kocka, de Bielefeld, e também os irmãos Hans e Wolfgang Mommsen, Rüsen assumia que o conhecimento histórico deveria se associar a uma "perspectiva positiva de futuro", que fosse capaz de auxiliar a jovem República Federal Alemã a correr atrás do tempo perdido. ${ }^{53}$ Nesse otimismo com a modernização política, econômica e social encontram-se fortes traços do que Moses chamou de "republicanismo redentor".

O mesmo se pode dizer da influência exercida sobre o pensamento de Rüsen pelo filósofo social que é o nome mais emblemático da posição republicana-redentora, a saber, Jürgen Habermas. Um dos traços mais marcantes da influência de Habermas sobre Rüsen encontra-se no argumento de que a lógica diretora da produção do conhecimento histórico está indissociavelmente ligada a interesses emanados da vida prática. Habermas foi um dos mais sofisticados críticos do que diagnosticava ser a "repressão do interesse" no ideal clássico de teoria, de Aristóteles a Edmund Husserl, pelo menos. Escrevendo em meados da década de 1960, Habermas enfatizava que era chegada a hora de se desfazer de uma ilusão há muito cultivada pela filosofia: a ideia de que existiria uma teoria pura, desvinculada de interesses provenientes de fora do processo cognitivo. ${ }^{54}$ Ele sugere que não teremos saído do horizonte

\footnotetext{
51 A precoce perda do pai, falecido em combate em 1944, coloca Jörn Rüsen na chamada geração dos “filhos da guerra" (Kriegskinder), ou seja, na mesma coorte que os cerca de um terço dos alemães nascidos entre 1933 e 1945 que perderam o progenitor paterno no decorrer da guerra. Ver: Hermann Schulz, Hartmut Radebold \& Jürgen Reulecke, Söhne ohne Väter: Erfahrungen der Kriegsgeneration (Berlin: Ch. Links Verlag, 2009). Rüsen testemunhou sobre o tema em documentário produzido com base no livro de Schulz, Radebold e Reulecke, que tem sido transmitido em diversas emissoras de televisão alemãs: Andreas Fischer (diretor), Söhne ohne Väter. Vom Verlust der Kriegsgeneration, 79 min (Alemanha: Moraki Film, 2007).

52 Rüsen foi, na sua própria interpretação, um estudante apolítico da tradicional Universidade de Colônia. Após ter obtido o grau de doutor em 1966 e ter trabalhado por cerca de três anos como consultor científico numa das principais fundações de apoio a estudantes da então Alemanha Ocidental, Rüsen transfere-se em 1969 para a Universidade de Braunschweig, na condição de assistente acadêmico da filósofa Elisabeth Ströker. Nessa ocasião, e um pouco sob a inspiração do clima de protesto inaugurado na primavera de 1968, ele candidatou-se ao Senado da universidade, tendo sido eleito, quase sem querer. A entrada precoce nesse colegiado universitário, cujos demais membros eram na sua imensa maioria professores efetivos, precipitou, segundo ele, um processo de aprendizagem política que continuaria pelas décadas a seguir. Jörn Rüsen, "Die Karriere eines Aussenseiters (Gespräch mit Anja Berger)", in: Karrieren unter der Lupe: Geschichtswissenschaftler, org. Anja Berger (Würzburg: Lexika, 2002), 28-37 (31-32). Para além disso, é importante frisar que o engajamento político de Rüsen expressou-se sobretudo no seu intenso envolvimento com temas, discussões, grupos de trabalho, periódicos e instituições ligados ao ensino e à didática da história.

${ }^{53}$ Rüsen, "Interview geführt von Thomas Sandkühler", 272: “A palavra-chave história social, ciência social histórica, estava ligada com uma nítida perspectiva positiva de futuro. Isso tinha tudo a ver com a época em que Willy Brandt fez campanha eleitoral com o slogan 'ousar mais democracia'. Era a época em que, no âmbito da história contemporânea, inspirada pela nova geração - à qual [além de Wehler e Kocka] também pertenciam os irmãos Mommsen, ganhava predominância a seguinte ideia: a Alemanha tem de correr atrás da modernização e é isso que estamos fazendo agora. E eu sentia-me envolvido nisso entusiasticamente. Isso tudo também ia ao encontro da minha própria atitude interna, ainda que eu não fosse um representante típico da geração de 68 ".

54 As conhecidas teses de Habermas acerca da relação entre teoria e prática em diferentes modalidades de conhecimento científico foram desenvolvidas no seu livro Conhecimento e interesse, de 1968. Mas em conferência
} 
epistemológico do objetivismo, 55 enquanto não abandonarmos de vez a pretensão a um conhecimento puro, divorciado de interesses; ou seja, enquanto não nos voltarmos para as relações que se constituem entre as formas de conhecimento científico e os tipos de interesse por conhecimento emanados da prática social. Interesses, segundo ele, são elementos constitutivos da lógica da cognição, sem os quais não teríamos os pontos de vista que nos permitem conceber a realidade como tal. ${ }^{56}$ Não surpreende, em todo caso, que Habermas evite derivar dessa crítica do objetivismo a conclusão cética de que a objetividade seria impossível, e de que o conhecimento nada mais seria senão a uma forma de ideologia elaborada apenas para fornecer legitimação a interesses particulares disfarçados. Eliminar ou controlar tais interesses é, para ele, uma meta metódica legítima e viável em todas as ciências. Mas a tarefa de evitar a "sedução de interesses particulares" forma apenas um dos lados do problema da objetividade, pois é preciso reconhecer a existência de "interesses fundamentais" na base de qualquer ciência, aos quais esta deve "não só o seu impulso, mas também as condições de possível objetividade". 57

A teoria da história de Rüsen aceita de maneira nada reticente que o conhecimento histórico é um conhecimento prático; que no plano geral ele existe para satisfazer a "carências de orientação" e "interesses cognitivos" emanados do domínio da vida prática, sob a mediação das "ideias", e com a finalidade de desempenhar "funções de orientação". 58 Admite também que esse caráter prático não invalida, nem obstaculiza as pretensões à objetividade da pesquisa e da escrita históricas, ainda que as torne consideravelmente mais complexas. ${ }^{59}$ Habermas, certamente, não inventou essa perspectiva de análise do conhecimento e o seu concomitante vocabulário - ambos estão impregnados de motivos marxianos e weberianos, por exemplo. Mas, na Alemanha, desde a década de 1970, é ele quem fornece a referência mais direta para o tipo e o estilo de análise do conhecimento que Rüsen desenvolveu nos anos 80, tendo em vista especificamente o conhecimento histórico. Além disso, a influência de Habermas também se faz notar fortemente sobre o conceito de "razão histórica" de Rüsen, o qual em vários níveis se situa na vizinhança da noção habermasiana de racionalidade comunicativa. ${ }^{60}$

É preciso destacar, por outro lado, que adaptações só aparentemente insignificantes caracterizam o aporte de conceitos habermasianos na teoria da história de Rüsen. Em diversos momentos, Rüsen parece procurar atenuar deliberadamente as conexões entre as suas reflexões e a "teoria crítica da ciência" de Habermas. Isso pode ser percebido claramente no próprio desenho geral da matriz disciplinar da ciência histórica. Aqui Rüsen abranda a expressão

homônima, ministrada por ocasião da sua investidura como professor na Universidade de Frankfurt em 1965, ele já havia traçado as diretrizes gerais da sua tentativa de renovar a filosofia da ciência submetendo-a ao filtro da teoria crítica. Jürgen Habermas, "Conhecimento e interesse", in: Habermas, Técnica e ciência como 'ideologia' (Lisboa: Edições 70, s/d), 129-147.

55 Segundo Habermas o "objetivismo" equivale à "atitude que relaciona ingenuamente os enunciados teóricos com os estados de coisas". Habermas, "Conhecimento e interesse", 136.

${ }^{56}$ Habermas, "Conhecimento e interesse", 141.

${ }^{57}$ Habermas, "Conhecimento e interesse", 141.

58 Jörn Rüsen, Razão histórica. Teoria da história I: os fundamentos da ciência histórica [1983] (Brasília: Ed. UnB, 2001), 29-33.

59 Rüsen, Razão histórica, 126-147; Jörn Rüsen, "Narratividade e objetividade nas ciências históricas", Textos de História, v. 4, n. 1, 1996, 75-102 (93-102).

${ }^{60}$ Rüsen, Razão histórica, 21-22; 128-129; 134-135; 140-147; 175-178. Acerca dos paralelos entre Rüsen e Habermas, ver Allan Megill, “Jörn Rüsen's Theory of Historiography between Modernism and Rhetoric of Inquiry”, History and Theory, v. 33, n. 1, 1994, 39-60 (52-53); Luiz Sérgio Duarte da Silva, "Ação comunicativa e teoria da história: aproximação de Habermas e Rüsen”, Philósophos, v. 5, n. 2, 2000, 145-161. 
habermasiana "interesses cognitivos", subdividindo o seu campo semântico. Noções como "carências de orientação", "ideias" e "perspectivas diretoras voltadas para a experiência do passado" passam então a absorver as funções discursivas que Habermas centralizara em "interesses cognitivos". ${ }^{61} \mathrm{O}$ mesmo também se pode inferir do fato de Rüsen fazer relativamente poucas referências explícitas à obra de Habermas. Em Razãa Histórica, por exemplo, o nome de Habermas é citado uma única vez e isso contrasta bastante com a atmosfera conceitual habermasiana que permeia boa parte do livro, e sobretudo o Capítulo $3 .{ }^{62}$

Hans-Jürgen Pandel afirma que a iniciativa de Rüsen de demarcar alguma distância em relação a Habermas se deve a diferenças relativas à orientação política de ambos. Segundo Pandel, Rüsen não queria "ser rotulado como um esquerdista". ${ }^{63}$ Essa estratégia certamente teve algum sucesso. Annete Kuhn - uma acadêmica que no campo da didática da história sempre assumiu posições abertamente "habermasianas" e que, por assim dizer, fala de maneira inequívoca a linguagem do republicanismo redentor - afirmou que "se fosse criticar Rüsen, recorreria a conceitos como "conservador". ${ }^{64} \mathrm{O}$ modo condicional da linguagem aqui não impede que a crítica seja efetivamente expressa, e tal crítica é sem dúvida indistinta. Mas fornece, ainda assim, uma percepção interessante que ajuda a compreender a maneira como Rüsen, nos anos 80, simultaneamente, se aproxima e se afasta de Habermas. Em comum com este (e também com Kuhn, para não falar dos já mencionados historiadores sociais), Rüsen valora positivamente o legado emancipatório do iluminismo, cultivando uma visão, no geral, bastante positiva do processo modernizador e mantendo, em boa medida, benevolência para com tradições que então se encontravam sob xeque, como a do pensamento utópico e a da filosofia substantiva da história.

Contudo, diferentemente de Habermas, Rüsen adere a um progressismo moderado por uma forte tendência antimarxista, o qual terá sido interpretado como demasiado à direita por intelectuais e estudantes mais ligados ou mais simpáticos aos protestos do final dos anos 1960 - tal como evidenciado na declaração de Kuhn. Recordando uma vivência de quando era ainda adolescente, Rüsen diz ter saltado no ar, "cheio de alegria", ao ouvir no rádio a notícia da morte de Stalin, em março de $1953 .{ }^{65}$ O próprio Rüsen estava consciente de que o seu antimarxismo o afastava do campo político mais à esquerda, no qual a figura de Habermas aparecia como uma referência intelectuais de enorme influência . "O que mais me afastou da geração de 68" - afirma ele em entrevista - "foi o marxismo. Isso eu não podia aceitar, porque eu cresci no contexto da Guerra Fria, observando a Alemanha Oriental, e tal era para mim, já na adolescência, já antes de ingressar na universidade, simplesmente a antítese de uma sociedade humanizada". ${ }^{60}$

${ }^{61}$ Rüsen, Razão histórica, 29-35.

62 Rüsen, Razão histórica, 145. Há também duas significativas menções a Habermas no livro subsequente, Reconstrução do passado. Teoria da história II: os princípios da pesquisa histórica [1986] (Brasília: Ed. UnB, 2007), 162; 171. A partir da década de 1990, no entanto, o diálogo (explícito ou implícito) de Rüsen com a obra de Habermas arrefece bastante. Em Teoria da história, por exemplo, não há sequer menção direta a textos ou ideias deste último.

${ }^{63}$ Hans-Jürgen Pandel, "Interview geführt von Thomas Sandkühler" [10. August 2012], in: Historisches Lernen denken: Gespräche mit Geschichtsdidaktikern der Jahrgänge 1928-1947, org. Thomas Sandkühler (Göttingen: Wallstein, 2014), 326-356 (339).

${ }^{64}$ Annete Kuhn, "Interview geführt von Thomas Sandkühler" [23. Oktober 2012], in: Historisches Lernen denken: Gespräche mit Geschichtsdidaktikern der Jahrgänge 1928-1947, org. Thomas Sandkühler (Göttingen: Wallstein, 2014), 164-192 (180).

${ }^{65}$ Rüsen, "Interview geführt von Thomas Sandkühler", 253.

${ }^{66}$ Rüsen, "Interview geführt von Thomas Sandkühler", 272. 
A hostilidade em relação ao marxismo é obviamente um aspecto que aproxima Rüsen dos teóricos da compensação egressos do Collegium Philosophicum de Joachim Ritter - filósofo a quem Habermas, a propósito, atribui um diagnóstico "neo-conservador" do presente, uma visão tecnocrática da modernização, a renovação da tradição da direita hegeliana, entre outras performances pouco laudáveis. ${ }^{67}$ Outro aspecto que aproxima Rüsen de Ritter e da Ritter-Schule é a estratégia de produzir teoria por meio da reinterpretação positiva de ideias e autores da tradição alemã de finais do século 18 e do século 19. Ritter, como já se observou, conecta a sua teoria da compensação a uma interpretação do diagnóstico hegeliano da modernidade. Rüsen, por sua vez, parte para uma teoria narrativista da historiografia e da cultura histórica fortemente inspirado pela Historik de Droysen. Em ambos os casos, a reinterpretação de autores da tradição do idealismo e do historicismo é conduzida de modo a adaptar aos parâmetros liberais e democráticos da Bundesrepublik ideias provenientes de horizonte de pensamento não democrático e só semiliberais. Habermas, em contraposição, manifesta uma certa rejeição da tradição intelectual alemã e uma aproximação decidida em relação à tradição liberal anglo-saxã. ${ }^{68}$ Mantem-se numa relação ambivalente em relação ao idealismo, mas a sua posição em relação à tradição posterior do historicismo é abertamente crítica: tratar-se-ia pura e simplesmente do "positivismo das ciências do espírito". ${ }^{99}$ Aqui encontramos um ponto nodal em que a teoria da história Rüsen se afasta do pensamento de Habermas para se cruzar com motivos caros ao grupo outrora reunido em torno de Ritter, em Münster.

A metade do caminho entre Frankfurt e Münster, se formos aventurosos o suficiente para fazermos o percurso a pé, fica em algum ponto da região das Montanhas de Rothaar, ao sul da Sauerland e ao norte de Siegen. Esse cenário idílico e esparsamente habitado poderia ser apresentado como o lugar metafórico da teoria da história de Jörn Rüsen, pelo menos no que se refere à posição que nela é defendida com respeito ao problema da função das ciências humanas e da história, em particular. Mas a metáfora, obviamente, diz muito pouco: a teoria de Rüsen, não é nem habermasiana, nem tampouco ritteriana, mesmo que se aproxime ou seja aproximável de aspectos centrais presentes nas teorias da ciência humanas de Habermas, Ritter e Marquard. Já foram mencionados elementos importantes que separam Rüsen de Habermas. Cabe agora voltar os olhos para o que o separa dos ritterianos e as razões essenciais de tal separação são explicitadas precisamente na crítica de Rüsen à teoria da compensação.

Rüsen pouco discutiu sistematicamente a tese da compensação. Mas em diversos textos publicados entre meados da década de 1980 e o início dos anos 2000, deixou bastante clara a sua divergência fundamental com relação ao ponto de vista elaborado por Ritter e,

\footnotetext{
${ }^{67}$ Jürgen Habermas, O discurso filosófico da modernidade: doze lições [1985] (São Paulo: Martins Fontes, 2000), 102107.

${ }^{68}$ Jens Hacke, Philosophie der Bürgerlichkeit. Die liberalkonservative Begründung der Bundesrepublik (Göttingen: Vandenhoeck \& Ruprecht, 2008), 22.

${ }^{69}$ Habermas, "Conhecimento e interesse", 131.
} 
depois, adaptado e disseminado por Marquard..$^{70}$ Em linhas gerais, Rüsen critica os partidários da compensação por tomarem o processo de modernização como um destino acerca do qual as humanidades nada teriam a dizer. É por isso que ele rejeita decididamente a ideia de que as ciências humanas se deveriam concentrar em proporcionar uma espécie de reservatório cultural com o qual os prejuízos causados pela modernização se tornariam mais suportáveis.

Tentando demonstrar que as ciências humanas apenas terão surgido posteriormente ao estabelecimento das modernas ciências experimentais da natureza, Odo Marquard comentou que estas últimas são "challenge", enquanto as primeiras seriam "response". Para ele, as ciências humanas são "insuperavelmente modernas", uma vez que surgem como meios de responder aos desafios produzidos pela enorme aplicabilidade do conhecimento experimental que caracteriza o mundo moderno. ${ }^{71}$ Rüsen rebate, em tom crítico, que com uma tal argumentação se institui uma divisão do trabalho científico em que as ciências naturais são mantidas como uma força ativa de transformação do mundo, ao passo que às ciências humanas se reserva o papel meramente reativo de tentar organizar, com a ajuda da memória, os desarranjos culturais ocasionados pela modernização. ${ }^{72}$ Para Rüsen, não basta acalmar a "vertigem", que acomete as modernas sociedades em rápida e constante transformação, simplesmente mediante a memória de identidades e formas de vida em vias de desaparecer. Ele aponta que tentar "compensar a falta de sentido por meio da memória histórica não faz muito sentido". ${ }^{73} \mathrm{Na}$ verdade, Rüsen exige que as ciências humanas, a história entre elas, avancem para bem além da produção de meios de compensação para perdas culturais. Ele enfatiza que tais ciências são capazes de proporcionar orientação, ou seja, de exercer influência sobre o processo real de transformação da vida social atual. ${ }^{74}$ As ciências da cultura, segundo ele, "não devem apenas remediar os estragos da modernização, mas também devem tomar parte na orientação cultural do processo modernizador" ${ }^{75}$

Muito mais do que a questão da tarefa das ciências humanas está em jogo nessa tomada de posição de Rüsen em favor de uma função orientativa em detrimento de uma função compensatória. Pode-se dizer que no centro da discussão entra aqui o próprio futuro, ou melhor, o problema: em que medida a história e as ciências que lhe são próximas podem ou devem se relacionar com as expectativas de futuro cultivadas no âmbito da vida social?

Não é difícil perceber que, quanto a este tema, a posição de Rüsen é bastante mais otimista do que a que predominou entre alunos de Ritter tais como Marquard, Hermann Lübbe e Robert Spaemann. Estes últimos, movidos pela consciência da conexão entre representações coletivas de futuro, ideologia e totalitarismo, partiram para uma crítica radical das modernas filosofias da história, de que resultou uma postura marcadamente antiutópica - e

\footnotetext{
${ }^{70}$ Jörn Rüsen, “Die Zukunft der Vergangenheit” [1998], in: Rüsen, Zerbrechende Zeit. Über den Sinn der Geschichte (Köln: Böhlau, 2001), 131-141; Jörn Rüsen, “Auf dem Weg zu einer Pragmatik der Geschichtskultur”, in: GeschichtsErzählung und Geschichts-Kultur. Zwei geschichtsdidaktische Leitbegriffe in der Diskussion, orgs. Ulrich Baumgärtner \& Waltrud Schreiber, München: Herbert Utz Verlag, 2001, 81-97 (87); Jörn Rüsen, "O que significa estudar ciências da cultura e para que estudá-las?” [2000], in: Rüsen, Cultura faz sentido. Orientações entre o ontem e o amanhã (Petrópolis: Vozes, 2014), 193-208.

${ }^{71}$ Marquard, "Sobre la inevitabilidad de las ciências del espíritu”, 111-112.

72 Para uma outra crítica à mesma divisão do trabalho, ver Kersting, "Hypolepsis und Kompensation", 185.

${ }^{73}$ Jörn Rüsen, "Interview conducted by Ewa Domanská" [11.11.1993], in: Encounters: Philosophy of History after

Postmodernism, org. Ewa Domanská (Charlottesville: University Press of Virginia, 1998), 138-165 (143).

${ }^{74}$ Rüsen, "Die Zukunft der Vergangenheit", 132-133.

${ }^{75}$ Rüsen, “Auf dem Weg zu einer Pragmatik der Geschichtskultur”, 87.
} 
cética em relação à possibilidade de se moldar o futuro por meio da ação racional coletiva amparada por interpretações histórico-filosóficas. ${ }^{76}$ Nisso, aliás, os egressos do Collegium Philosophicum de Ritter convergem com a posição de Reinhart Koselleck, que não só foi um grande historiador das grandes representações filosóficas da história, mas também um dos seus mais decididos críticos. ${ }^{77}$

Rüsen não compartilha desse grau de ceticismo quanto às teorias do sentido da história e ao pensamento utópico. Ele faz questão de manter as ciências humanas a uma certa distância de tais tradições, ao mesmo tempo em que preserva relevantes zonas de comunicação entre elas. Isso se percebe bem quando Rüsen destaca que o pensamento histórico e o pensamento utópico se originam, ambos, do mesmo superávit de intenções e da mesma dinâmica de geração de expectativas que caracterizam o agir e o viver humanos. ${ }^{78}$ "Sem o exercício da lembrança pelo pensamento histórico" - afirma ele - "não seria possível uma orientação eficaz do agir; por outro lado, a vida prática humana não pode abrir mão de articular as abundantes carências que apontam para além do seu horizonte de experiência". ${ }^{79}$ Rüsen sabe, no entanto, que as utopias, diferentemente das histórias, fornecem a esse mesmo agir interpretações e orientações desvinculadas da experiência, as quais frequentemente se lhe estão até mesmo opostas. A conclusão de Rüsen é a de que a vida prática humana é enriquecida pela tensão entre história e utopia e pelo ambiente de crítica recíproca que pode brotar desta tensão - desde que se avance para um pouco além da mera crítica desconstrutiva de uma à outra. ${ }^{80}$

À luz dessa percepção, Rüsen sugere que o antiutopismo que informa as teorias da compensação acaba por conduzir a um divórcio - para ele, indesejável e não necessário - entre os processos cognitivos das ciências humanas e as implicações práticas das decisões, ações e interações com as quais se determina o futuro real das sociedades. No entender de Rüsen, um teórico como Marquard terá ido longe demais na sua tentativa de isolar as ciências humanas com um cordão sanitário que as protegesse da ideologização. O abandono radical das utopias tê-lo-ia levado a propor que as ciências humanas se abstivessem da pretensão de atuar como uma "força cultural de configuração do futuro". ${ }^{81}$

Semelhante desconexão entre história e futuro também seria perceptível num importante argumento sobre a função da historiografia desenvolvido por outro egresso do Collegium Philosophicum de Ritter, Hermann Lübbe. Segundo este, "as histórias narradas são meios da apresentação da identidade, de si e dos outros, e ninguém pode encontrar a sua própria

\footnotetext{
${ }^{76}$ Hacke, Philosophie der Bürgerlichkeit, 48-52.

77 Niklas Olsen, History in the Plural. An Introduction to the Work of Reinhart Koselleck (New York: Berghahn, 2012), 50-52; Arthur Alfaix Assis \& Sérgio da Mata, "Prefácio: O conceito de história e o lugar dos Geschichtliche Grundbegriffe na história da história dos conceitos”, in: R. Koselleck et al., O conceito de história (Belo Horizonte: Autêntica, 2013), 9-34 (21-22).

${ }^{78}$ Rüsen, História viva, 139-141.

${ }^{79}$ Jörn Rüsen, "Geschichte und Utopie”, in: Handbuch der Geschichtsdidaktik [1979], org. Klaus Bergmann et al. (Seelze: Kallmeyer, 1997), 76-80 (77).

${ }^{80}$ Rüsen, "Geschichte und Utopie", 78.

${ }^{81}$ Rüsen, “O que significa estudar ciências da cultura e para que estudá-las?”, 208.
} 
identidade sem representar a identidade alheia". ${ }^{82}$ Rüsen, com efeito, endossa a orientação pragmática da teoria da historiografia de Lübbe e pode até mesmo ser apontado como um continuador da perspectiva analítica avançada por este, segundo a qual a historiografia guarda uma íntima e essencial relação com as identidades dos seus produtores e destinatários. Mas Rüsen considera tal perspectiva insuficiente, uma vez que esta se restringe a considerar de modo não-normativo as identidades como pressupostos relativamente fixos do agir humano. ${ }^{83}$ Para ele, tais identidades não são simplesmente fatos imutáveis, mas antes produtos da interação entre fatos e normas, entre experiências do passado e expectativas de futuro. ${ }^{84}$ Representações normativas de futuro têm, portanto, impacto sobre a dinâmica identitária na qual o conhecimento histórico pode entrar como um fator relevante. Por isso, as histórias não somente apresentam identidades pré-existentes, esclarecendo os atores do presente quanto às condições do seu agir. Elas também remetem esses dados prévios da experiência a normas e intenções dirigidas à transformação do mundo e, com isso, penetram na dinâmica interna do agir.

Com isso também ganham novamente uma forma conexão com o futuro que Lübbe procurou deliberadamente desfazer, sob a nobre intenção de imunizar as ciências históricas contra eventuais abusos ideológicos (que nos anos 1970 não eram nada incomuns na Alemanha Oriental). Assim como Lübbe, Rüsen também repudiava o tipo de futuro ao qual a tradição marxista orientava as suas esperanças e a sua ação coletiva. Mas Rüsen considerava duvidosa uma premissa estruturante da pragmática não-normativa da historiografia desenvolvida por Lübbe (a qual, na verdade, está enraizada já na teoria da compensação de Ritter ${ }^{85}$ ): a de que os processos reais, em marcha nas sociedades contemporâneas, conduziriam a uma espécie de futuro inexorável, acerca do qual somente cientistas da natureza, economistas e cientistas políticos teriam algo a dizer. Neste contexto, a naturalização do futuro e a sua total rejeição como horizonte para as interpretações do passado feitas pelos historiadores culminaria com o esvaziamento do sentido do próprio pensamento histórico. ${ }^{86} \mathrm{Com}$ isso, segundo Rüsen, nada mais restaria ao agir dirigido ao futuro senão as orientações fornecidas pela racionalidade instrumental, que predomina no campo das ciências naturais, da técnica e da economia. Uma tal racionalidade é capaz de balizar o ajuste de meios a fins, mas não pode fornecer base para os processos de escolha nos quais se determina a relevância desses mesmos fins. ${ }^{87}$

No seu famoso texto sobre a vocação do cientista, Max Weber já havia indicado com precisão o significado e os limites dessa racionalidade instrumental, sob cujo jugo Rüsen não quer ver as ciências humanas. Argumentando que a ciência não nos pode dizer como devemos viver, Weber acrescenta que ela também não nos diz o que devemos querer: "Se a vida vale a pena ser vivida e quando - esta questão não é indagada pela medicina. A ciência natural nos dá uma resposta para a questão do que devemos fazer se desejamos dominar a vida tecnicamente.

${ }^{82}$ Herman Lübbe, "La funcción de presentation de identitidad de la historia", in: Lübbe, Filosofía práctica e teoría de la historia (Barcelona: Alfa, 1983), 109-129 (119).

${ }^{83}$ Jörn Rüsen, "Kritik des Neohistorismus", Zeitschrift für philosophische Forschung, v. 33, n. 2 (1979), $243-263$ (255256).

${ }^{84}$ Rüsen, "Kritik des Neohistorismus", 258.

${ }^{85}$ Ver Lübbe, Geschichtsbegriff und Geschichtsinteresse, 324-356.

${ }^{86}$ Rüsen, "Auf dem Weg zu einer Pragmatik der Geschichtskultur”, 87.

${ }^{87}$ Rüsen, “O que significa estudar ciências da cultura e para que estudá-las?”, 199-201. 
Deixa totalmente de lado [...] se devemos e queremos realmente dominar a vida tecnicamente e se, em última análise, há sentido nisso". 88

Uma premissa fundamental da crítica de Rüsen à "compensação" é a de que questões sobre objetivos, finalidades, sentidos, tais como as mencionadas por Weber, são respondidas de maneira disfuncional quando são consideradas apenas sob o prisma da racionalidade instrumental, contra a qual, segundo ele, a teoria da compensação é ineficaz. É claro que se pode discutir, com base por exemplo em diferentes correntes da psicologia contemporânea, sobre se tais questões não extrapolariam o domínio da racionalidade em qualquer sentido possível do termo. Mas Rüsen, na esteira de Weber, insiste que aqui, entre o racionalinstrumental e o irracional, age ou pode agir uma racionalidade diversa. Pode-se falar, à falta de um termo melhor, de uma "racionalidade de sentido", apta a promover nos indivíduos a capacidade de refletir com clareza sobre consistência, conectividade e exequibilidade de valores, escolhas e finalidades. ${ }^{89}$

É, assim, pela via da racionalidade de sentido que Rüsen pretende ligar a história e as ciências humanas ao futuro. Isso quer dizer, antes de mais nada, que, para ele, a tarefa dessas ciências não é prever o futuro por meio de macro-interpretações que desvendem o sentido da história. Por outro lado, entretanto, continua sendo central à teoria da história de Rüsen, em todas as suas versões, a noção de "sentido histórico", proveniente da tradição da filosofia substantiva da história. Do mesmo modo que evita uma crítica radical do pensamento utópico, Rüsen não rejeita a tradição da filosofia da história - pelo contrário, na Teoria da história, assimila-a e reelabora-a, diferenciando entre as filosofias material, formal e funcional da história. ${ }^{90}$ Paralelamente, Rüsen transfere a noção de "sentido" do domínio do processo histórico como um todo para o da ação prática. Ele insiste que cabe a história interpretar a experiência do passado gerando representações do decurso do tempo que sejam compatíveis com metas de ação. Ao mesmo tempo em que abre mão de premissas teleológias em sentido forte, como por exemplo a de que a história caminharia na direção da ampliação da liberdade ou do progresso social, Rüsen mantem o pensamento histórico conectado a uma teleologia fraca, isto é, à teleologia que na própria práxis humana caracteriza o agir. O agir (bem como o sofrer) é sempre teleológico, posto que dirigido à realização de um fim antecipado na forma de intenções. Intenções, por sua vez, são dirigidas ao futuro e por este caminho complexo Rüsen encontra um modo muito original de continuar a fazer valer o futuro enquanto instância de determinação da tarefa do conhecimento histórico. ${ }^{91}$

Os teóricos da compensação argumentam que as ciências humanas devem se abster da problemática do futuro; que devem se contentar com a tarefa de gerir o passado e de tornálo familiar a um presente que dele estará cada vez mais estranhado. Rüsen enxerga um risco

\footnotetext{
${ }^{88}$ Max Weber, “A ciência como vocação” [1917], in: Weber, Ensaios de sociologia (Rio de Janeiro: LTC, 1982), 154183 (171).

${ }^{89}$ Wiklund, "Além da racionalidade instrumental", 39-40. Sobre o tema da racionalidade de sentido em Weber, ver Wolfgang Schluchter, "Politeísmo dos valores: uma reflexão referida a Max Weber", in: A atualidade de Max Weber, org. Jessé Souza (Brasília: Ed. UnB, 2000), 13-48.

${ }^{90}$ Rüsen, Teoria da história, 114-150.

91 Jörn Rüsen, "Pode-se melhorar o ontem? Sobre a transformação de passado em história" [2002], in: História, verdade e tempo, org. Marlon Salomon (Chapecó: Argos, 2011), 259-290 (271-274). Sobre o tema ver Caio Rodrigo Carvalho Lima, Além dos muros da academia: sentido da história e trauma histórico na obra de Jörn Rüsen - 19832013 (Dissertação de mestrado em História, Universidade de Brasília, 2016), cap. 1.
} 
nessa redução da ressonância temporal potencial das ciências humanas, que as converte em ciências do passado, num sentido bastante estrito. O risco é o de que, mesmo contra as melhores intenções dos teóricos da compensação, as ciências humanas acabem por reforçar uma cultura cada vez menos histórica, em que o passado se descola radicalmente do futuro. Se isso acontecer, segundo ele, os efeitos sobre a nossa subjetividade serão catastróficos. Perspectivas de futuro inteiramente descoladas da lembrança do passado carecem precisamente daqueles aspectos que fazem com que o futuro seja "o nosso futuro". Tal processo equivaleria ao esfacelamento da nossa identidade. Quando o que fomos no passado não pode ser levado para o futuro em direção ao qual queremos conduzir as nossas vidas, o que sucede é que "nós nos perdemos no futuro e deixamos de o possuir". "No pior dos casos" - conclui Rusen - "é o futuro que nos possui, impedindo que nós próprios possamos ser donos de nós mesmos. Mas isso então não mais seria um futuro para nós; seria antes um futuro contra nós". ${ }^{92} \mathrm{Em}$ última análise, é o receio da perda de si como perda do e no nosso próprio futuro que levou Jörn Rüsen a se colocar contra a compensação. ${ }^{93}$

${ }^{92}$ Rüsen, "Die Zukunft der Vergangenheit”, 133.

93 Agradeço a Sérgio da Mata os comentários críticos a uma versão deste texto, que me ajudaram a matizar diversos aspectos da interpretação. 